\title{
Methodical approach to isolation of seismic activity migration episodes of the northeastern Baikal rift system (Russia)
}

\author{
Institute of the Earth's Crust, Siberian Branch of RAS, Irkutsk, Lermontov Street 128, 664033 Irkutsk, Russia; \\ *Corresponding author, E-mail: avn@crust.irk.ru, olgal@crust.irk.ru
}

(Received: August 8, 2019; Revised accepted: March 31, 2020)

https://doi.org/10.18814/epiiugs/2020/020058

The orientation of deformation process development during rifting controls the strike of the regional active faults, which determine the epicentral field structure features in the northeast part of the Baikal rift system (BRS), characterized by current high seismic activity. Rose charts were plotted for the number of faults of each strike range. For zones of epicenter concentrations, the polygons of seismic data projection were determined in accordance with the general strike of most of the active faults and their average length. Taking into account the anisotropy of the fracture network, the spatiotemporal analysis of the earthquake epicentral field was carried out using GIS technology. The seismic activity migration episodes as a result of crustal deformation are inherent to a non-stationary seismic process for the investigated area. Migrations, characterized by constant rate, are recurred in places of intense lithosphere fracturing and change the direction in potential $M \geq 5$ earthquake and swarms occurrence sites. Ordered sequences of energy clusters most likely propagate at a depth of the fluid-saturated layer beneath the thickened granite batholith where the heat accumulated warms up the fluid and apparently reduces the viscosity of seismoactive layer. The existence of thickened plastic lithospheric layer and viscosity reduction of brittle crustal layer are conditions probably conducive to migration of seismic activity.

\section{Introduction}

The Baikal rift system - one of the largest continental rifts - is located in the southern East Siberia extending a distance of about $1800 \mathrm{~km}$ from the northeast to the southwest. The rift system is a combination of horsts and grabens affected by the faults, which have been active since the Early Holocene (Sherman et al., 1992). The density of the crustal fracture network is related to neotectonic movement intensity and tectonic deformation rates. The area under investigation, situated in the northeastern BRS, is characterized by high strain rates (Lukhnev et al., 2013), fault density, earthquake and earthquake swarm numbers.

The study area includes the Barguzin, Kitchera, Upper Angara, Muyakan and western Muya depressions, bordered by seismically active deep normal faults and the left-lateral strike-slip faults (Lukhnev et al., 2010), mainly of northeast strike (Fig. 1) (Petit and Déverchère, 2006). Major seismic gaps are oriented along the main branches of northeastern BRS. However, there are epicentral clusters, which are aligned subpendicular to the strike of these structures. The regional faults of northeast and southwest strike reflect the current stage of rift evolution. Fault zone development, accompanied by seismicity, is associated with brittle deformation of the Earth's crust in continental lithosphere. The fracture network formed under the influence of deformation forces is characterized by anisotropy, which determines the spatiotemporal structure of the epicentral field (Lukhneva et al., 2010). An order of the tectonic activation of faults expressed in ordering of earthquakes occurrence (Bornyakov et al., 2014). The migrations of cumulative seismic energy, marking the deformation front propagation, are initiated by a strong event or by a swarm of earthquakes and are systematically observed mainly along the main fault lines (Novopashina and Sankov, 2018). The migration phenomenon is well traced using spatiotemporal analysis of the cumulative released seismic energy (parameter $\operatorname{LgE}_{\text {sum }}$ ), which is one of the main characteristics of earthquakes.

The most widely accepted hypothesis explaining the cause of migration of seismic activity is stress transfer in the crust by elastic and viscoelastic mechanism as a result of fault interaction (Politz et al., 2013; Tung and Masterlark, 2018; Žalohar, 2018). The differences in existing mechanisms probably determine the wide range of the migration rates, varied from centimeters and kilometers per second (Shelly, 2010) or per day (Obara and Hirose, 2006) to a few kilometers per year (Rydelek and Sacks, 2001) - 100 kilometers per year (Sherman and Gorbunova 2008; Levina and Ruzhich, 2015; Novopashnina and San'kov, 2015; Bykov, 2018) in different seismic zones in continental lithosphere. Episodes of the seismic activity propagation from the initial shock to subsequent events have been reported and described for many areas, including California (Lin and Stein, 2004), Turkey (Stein et al., 1997), Central Asia, Chile (Ding and Lin, 2014), New Zealand (Steacy et al., 2014), Northern Italy (Cheloni et al., 2016), Kamchatka (Vikulin et al., 2016; Dolgaya et al., 2016), Nepal (Tung et al., 2018) Mongolia (Pollitz et al., 2003), Cis-Baikal (Sherman, 2013; Gorbunova and Sherman, 2012; Levina and Ruzhich, 2015; Ruzhich et al., 2016), and other regions. The seismicity visualization method, used herein, was implemented to determine the parameters of slow earthquake sequences with notes of a few kilometers to a few hundreds of kilometers per year. Migra- 
tions characterized by such rate, were previously recorded in Central Asia and the Cis Baikal (Sherman, 2013; Gorbunova and Sherman, 2012; Levina and Ruzhich, 2015; Novopashina and Sankov, 2018). The results of detailed studies of earthquake sequences in the northeast part of the BRS with a description of lithosphere properties, where sequences occur, are presented in Novopashina and Kuz'mina (2019). The migration rate directly depends on the relative velocity of plate interaction in the region. The velocity field of horizontal displacements, strain and rotation rates of the Earth's crust in the Baikal region have been calculated (Lukhnev et al., 2010) based on multiyear measurements using the GPS geodesy method for the Mongol-Baikal geodynamic polygon over the period 1994-2007.

To determine the true deformation front direction, a spatial comparison was made between the episodes of migration and the location of fault lines. Previous studies showed that ordered sequences of earthquakes are recorded along the main seismic gaps in the zones, which are around $100 \mathrm{~km}$ wide. For this reason spatiotemporal analysis should take into account the anisotropy of fracture network, reflecting young geodynamic processes. This research presents the results of a geo-information analysis of the cumulative energy of earthquakes, released during the different time periods, within the areas of seismic data projection seeing the anisotropy of fault network. Our approach makes it possible to determine with higher precision the direction of deformation front propagation in areas of weakening (fragmentation) of the earth's crust. Three areas of study (Fig. 1) are defined as detailing zones in places where seismic energy distribution were previously recorded (Novopashina and Sankov, 2018; Novopashina and Kuz'mina, 2019). In order to assess the stationarity of the seismic regime for each projection area, spatiotemporal diagrams of the released seismic energy, plotted for two different periods of seismic activation, were compared.

The aim of this study is the accurate determination of the location and directions of systematic occurrence of migrations in seismic process to predict the spatiotemporal localization of potential foci of strong earthquakes and swarms, as well as areas of residual stress relaxation induced by strong events. For data analysis, the information-software environment is applied, including geographic information system (GIS) data of different functional characteristics and data exchange tools. This is due to the necessity of using of many types of software, each of which allows one to solve a specific problem of processing, presentation and geodata integration.

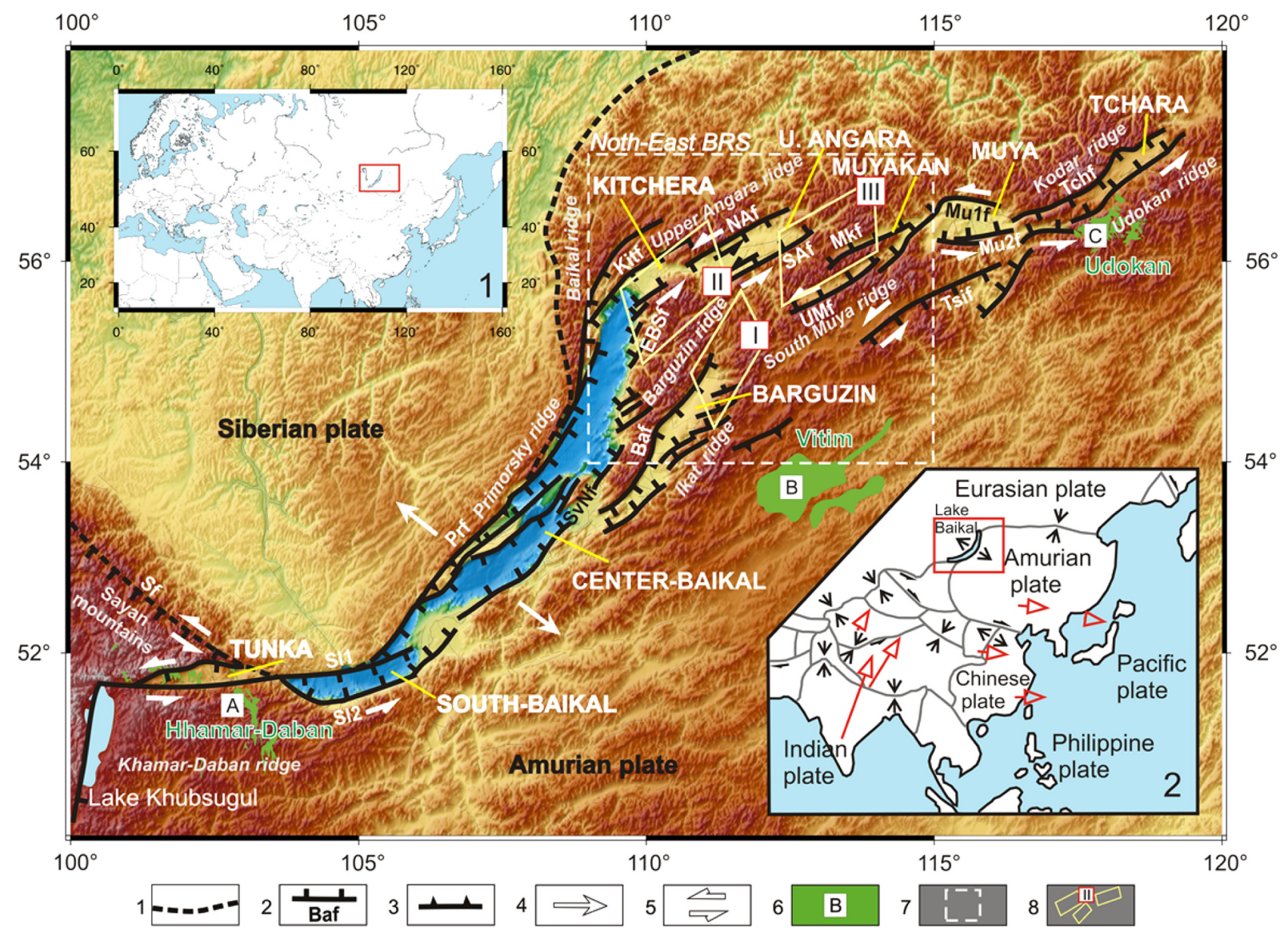

Figure 1. The general tectonic setting of the Baikal rift system (BRS): 1 - boundary of the Siberian platform, 2 - normal faults and oblique slips (Sf-Sayan fault, Sl1 - Southern lake fault 1, Sl2 - Southern lake fault 2, Prf-Primorsky fault, SvNf-Svyatoy Nos fault, EBSf-Ezovsko-Bolsherechensk system of faults, Baf-Barguzin fault, Kit-Kitchera fault, NAf-North Angara fault, SAf-South Angara fault, Mkf-Muyakan fault, UM1f, UM2f-Upper Muya fault 1 and 2, Muf-Muya fault, Tsif-Tsipican fault, Tchf-Tchara fault) (Petit et al., 1996; Mats et al., 2001), 3 reverse faults (Mats et al., 2001), 4 - age of oldest Cenozoic sediments (in circles: 0 -Eocene, 1 -Oligocene, 2-Miocene, 3 -Late Miocene/Pliocene) (Petit and Déverchère, 2006), 5 - divergent arrows (Lukhnev et al., 2010), 6 - arrows of transtension (Mats et al., 2001), 7-volcanics with their age (in squares: $A$ - Late Cretaceous, B - Paleogene, C-Miocene to Quaternary) (Petit and Déverchère, 2006), 8 - the study area (northeast BRS), 9 the study zones of seismic data projection with their numbers (Roman numbers in squares). Sidebar 1-geography features of the BRS. Sidebar 2 global tectonic features of the BRS (Thybo and Nielsen, 2009). 


\section{Geological setting}

The Baikal rift system, extending up to $1800 \mathrm{~km}$, is located within the Paleozoic Sayan-Baikal fold belt, which provides a divergent boundary between the stable Siberian and mobile Amurian (or North China) lithospheric plates, moving apart with transtension (Lukhnev et al., 2010) (Fig. 1). Western boundary of the Amurian plate moves eastward relative to the Siberian craton at a rate of first millimeters per year (e.g., Wei and Seno, 1998; Calais et al., 2003). The minimal rate of horizontal crustal movements in the northeastern BRS is $3.4 \mathrm{~mm}$ per year (San'kov et al., 2000). The rates of vertical movements of the BRS do not usually exceed $10 \mathrm{~mm}$ per year (Sankov et al., 2017). The rift system is a complex of faults and rift basins separated by topographic rises, reaching 2500-3000 $\mathrm{m}$ in elevation. The largest water-filled basin Lake Baikal - which is around $800 \mathrm{~km}$ long and $40-80 \mathrm{~km}$ wide, occupies the central part of the rift and contains the South and North depressions (Krivonogov and Safonova, 2017). The oldest South Baikal basin began to form at the end of the Upper Cretaceous-Paleocene (Logatchev, 2003) on the ancient folded basement whose formation episodes were well under way in the time periods of the Paleozoic and Mesozoic (Petit and Déverchère, 2006). The rest of the basins which continued their development in the Cenozoic are waterless and significantly smaller (Fig. 1): from 120 to $150 \mathrm{~km}$ long and from 30 to 40 $\mathrm{km}$ wide. The Baikal rift basins become younger towards the flanks.

Some authors agree that rifting is caused by upwelling of the asthenosphere beneath the Baikal rift zone (Logatchev, 1984, 1993; Zorin and Turutanov, 2003) (a model of active rifting). An alternative hypothesis for the origin of the BRS (passive rifting) relates to the Indo-Eurasian collision (Tapponnier and Molnar, 1979; Zonenshain and Savostin, 1981; Thybo and Nielsen, 2009). There is also the assumption that both active and passive mechanisms take place in the Baikal rift zone contemporaneously (Petit et al., 2008). In (Mats, 2012), it is supposed that a model of passive rifting corresponds to the early (Late Cretaceous, Paleocene and Early Eocene) and middle (Middle Eocene) stages of rifting, and a model of active rifting - to the current stage that lasts since the Late Pliocene ( 3.5 million years ago). The Baikal system is characterized by basaltic magmatism of a rather monotonous composition, related paragenetically to the neotectonic structure (Logachev, 1984).

The geodynamic regime of the southern East Siberia and adjacent North Mongolia did not significant change from the Early Holocene to the present day. This period is characterized by features of activation when rejuvenation affects primarily the NE-SW and east-west-striking faults. A combination of disjunctives of different kinematic types is a result of regional tectonic paragenesis during the Late Cenozoic under the influence the NW-SE extension and NE-SW compression dominating most of the area considered. The central part of the rift system exhibits horizontal crustal movements with a tensile stress field where normal faults and strike-slip faults are localized. The areas of horizontal crustal movements exhibiting shear stress fields dominate the southwestern and northeastern flanks of the Baikal rift system where the left-lateral strike-slip faults and oblique slips increase in number. Throughout the BRS, normal faults make up 54\%, left-lateral strike-slips $-10.6 \%$, left-lateral strike-slip faults $-8.2 \%$, reverse faults $6.2 \%$, left-lateral oblique slips $-5.8 \%$, and left-lateral reverse slips $4 \%$ of the total number of kinematic types (Lunina, 2016).

The northeast part of the BRS under investigation includes the areas of the Barguzin, Kitchera, Upper Angara and Muyakan, western Muya rift basins (Fig. 1), representing bilateral grabens filled by thick (2-3 km) Cenozoic sediments. The focal mechanisms of earthquakes which occurred in the Barguzin, Kitchera, Upper Angara, Muyakan and Muya grabens exhibit near-horizontal NW-SE strike of tensile/ intermediate stresses orthogonal to the rift axis and near-vertical orientation of compression axes. The Muyakan and Muya graben areas are also characterized by sub-meridional direction of tensile stress axes (Sherman et al., 1984).

Most of the basin-bordering faults in the investigated area are normal faults, with a variable amount of strike-slip (Petit et al., 1996), which have been active since the Pliocene-Quaternary ( 5 million years ago) (Melnikov et al., 1994; Logachev, 2003) (Table 1). Many of ancient faults (Precambrian) were reactivated in the Cenozoic and they are still active today. Vertical amplitudes of the basin-bordering normal faults in the northeastern BRS are ranging from several hundred meters to several kilometers. The strike-slip horizontal amplitudes are more than 2 kilometers (Mats et al., 2001).

The Barguzin basin, initiated in the Late Miocene (10-5 million years ago) (San'kov et al., 2000), is bounded by the SW-NE trending Barguzin normal fault (the Barguz in Branch) (Table 1) on the northwest and by a series of normal faults, separating the basin from the Ikat range, on the southeast (Fig. 1). The basin infill is asymmetric due to a greater (more than $2.5 \mathrm{~km}$ ) sediment thickness on its western side near the Barguzin range (Epov et al., 2007). The Barguzin graben is dominated by extensional stress state and normal faults (Lunina and Gladkov, 2007).

The Kitchera and Upper Angara basins initiated in the Late Miocene-Pliocene (10-3 million years ago) are bounded by the Kichera normal fault and Upper Angara strike-slip fault (Table 1) on the northwest and north respectively (Sherman et al., 1984). On the southwest,

Table 1. Structural parameters of faults in the northeast BRS according (Sherman et al., 1984; San'kov et al., 2000; Lunina, 2016)

\begin{tabular}{|c|c|c|c|c|c|c|c|c|}
\hline Main fault (branch) & $\begin{array}{c}\text { Strike } \\
\left({ }^{\circ}\right)\end{array}$ & $\begin{array}{c}\text { Dip } \\
\left({ }^{\circ}\right)\end{array}$ & $\begin{array}{c}\text { Angle of } \\
\text { dip }\left(^{\circ}\right)\end{array}$ & $\begin{array}{c}\begin{array}{c}\text { Depth } \\
(\mathrm{km})\end{array} \\
\end{array}$ & Cinematic type & Age of reactivation & $\begin{array}{l}\text { Vertical ampli- } \\
\text { tude (m) }\end{array}$ & $\begin{array}{l}\text { Total throw } \\
(\mathrm{m})\end{array}$ \\
\hline Barguzin & $25-50$ & 153 & $55-89$ & $38-45$ & normal fault & Holocene & $500-2000$ & 4900 \\
\hline Kitchera & $48-60$ & $138-150$ & $55-85$ & 50 & normal fault & Holocene & $2000-4000$ & 3300 \\
\hline Ezovsko-Bolsherechensk system & 40 & 310 & - & - & normal fault & Neogene-Quaternary & - & - \\
\hline North Angara & 63 & 153 & $50-75$ & - & left-lateral strike-slip fault & Holocene & $2000-3500$ & 4100 \\
\hline South Angara & 65 & 335 & $30-40$ & - & left-lateral strike-slip fault & Holocene & - & 2500 \\
\hline Muyakan & 60 & 330 & $60-80$ & $23-24$ & left-lateral strike-slip fault & Holocene & $800-1500$ & 800 \\
\hline Upper Muya & 55 & 325 & $60-85$ & 20 & left-lateral strike-slip fault & Holocene & $>2000$ & 800 \\
\hline
\end{tabular}


the Kitchera basin is bounded by the Ezovsko-Bolsherechensk system of normal faults, and the Upper Angara basin - by the South Angara strike-slip fault. The area of intrarift uplift between the Kitchera, Barguzin and Upper Angara basins (Barguzin intrarift uplift) is disturbed by numerous NW-SE-trending oblique strike-slip faulting events.

The Muyakan basin, which emerged at the boundary between the Miocene and Pliocene periods (10-3 million years ago) (San'kov et al., 2000), is bounded on the southeast by the Muyakan branch (Table 1) represented by a complex of NE- and ENE-striking faults. The authors report mainly the left-lateral but sometimes also the right-lateral strike-slip faults and strike-slips on the northern side of the Muyakan basin (Sankov et al., 1991). The Muya basin that occurred in the Quaternary (2-1 million years ago) is bounded by the Muya oblique slips on the northwest and southeast (San'kov et al., 2000).

Nowadays the BRS experiences about 700-800 earthquakes in a month, which rarely exceed magnitude 5.5 but reach magnitude 7 or more in certain parts (Solonenko and Solonenko, 1987; Radziminovich et al., 2013). Most of the earthquakes occur in the northeast BRS at a depth of $10-30 \mathrm{~km}$. Most of the focal depths are 10-20 km (Radziminovich, 2010). The maximum hypocentral depth is $50 \mathrm{~km}$. The earthquake hypocenters are sometimes located in the upper mantle (Déverchère et al., 1991, 2001). The projections of hypocenters on the earth's surface are concentrated in the basins, because the basin-bordering normal faults are flattening out in the middle crust and lower.

\section{Data and Methods}

\section{Data Analysis Technique}

For seismic process development tracing, the seismologic data collection is carried out in projection zones covering linear tectonic structures, which are marked by concentrations of epicenters of earthquakes of different intensities.

The projection zones are set in 1C:GIS Spatial Data Management with the Modules: ERP and 1C:KA2 (2019) by indication of the center point and azimuth of the spatial axis rotation position (Fig. 2). Zone size is determined by the length (L) and width (W) of the epicenter concentration area clearly visible on the map of epicenters. Fig. 2, a, b, c illustrate the sequential occurrence of groups of seismic events along the fractured space. Fig. 1, d shows schematically the summation result of the seismic energy inside cells of the data projection zone. For displaying the values of cumulative seismic energy from minimum to maximum, a gradient fill from green to red color is used for each cell (Fig. 1, d). An algorithm for calculating this parameter inside cells of size $\Delta \mathrm{L}=0.1^{\circ}$ is implemented in the $1 \mathrm{C}$ : GIS.

Azimuth of rotation position depends on the prevailing direction of the seismic gaps. For this reason, initial anisotropy of the fracture net has been analyzed within a radius of $75 \mathrm{~km}$, which corresponds to the average length of the most regional faults in this part of the BRS, which are about $150 \mathrm{~km}$ long. Thus, the used grid radius covers general dislocations of length $90-150 \mathrm{~km}$ (Sherman et al., 1984). The number of faults that fall within 15-degree segments is calculated in the 1C-system. Using the map of active faults (Lunina, 2016), rose charts of the dislocation directions, showing the fracture anisotropy, were calculated for each projection zone center. The azimuth of the spatial axis

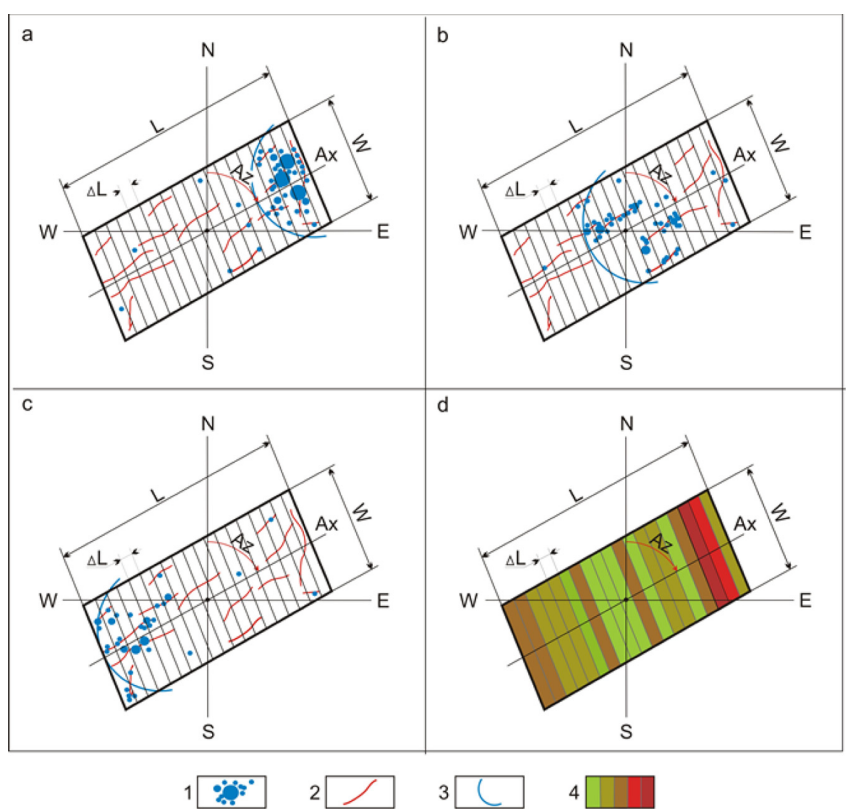

Figure 2. The principle scheme showing the earthquake data collection process in projection areas: $a, b, c$-position of earthquake clusters occurring sequentially over the successive time periods, $d$ - filling of the projection zone cells by color depending on the logarithm of the total seismic $\left(L_{g} E_{\text {sum }}\right)$ energy over the total investigated period (t) from green (minimum value) to red (maximum value). 1 -clusters of hypothetical earthquakes of different intensity, 2 - hypothetical active faults, 3-deformation front, 4-LgEsum over the entire time period. Ax-spatial axis.

of the projection areas was set within the range of rose charts maximum values.

The spatiotemporal plots of set projection zones (I, II, III) with axes of time, distance (spatial dimension) and energy parameter - decimal logarithm of total realized earthquake energy $\left(\lg \mathrm{E}_{\text {sum }}\right)$, were plotted by the MathJL software (2019). The parameter $\mathrm{LgE}_{\text {sum }}$ was calculated using the data of the Baikal Regional Seismological Center, Geophysical Survey of the Russian Academy of Sciences (BRSC GS RAS, 2019) over the instrumental period 1964-2010. The map displays the cumulative energy for the entire study period obtained in each elementary cell of projection area as: $\operatorname{LgE} \mathrm{E}_{\text {sum }}=\lg \left(\sum_{i=1}^{n} E_{i}\right)$, where $\mathrm{n}$ is the number of seismic events, $E$ is earthquake energy (J) (Fig. 2). Size of unit cell is a distance $\Delta \mathrm{L}$ of $0.1^{\circ}$. Plotting of spatiotemporal $\mathrm{LgE}_{\text {sum }}$ graph involves summation of energy of shocks over the period of time $\Delta \mathrm{T}=1$ month within projection cells followed by interpolation using the three by three point window. The $\mathrm{LgE}_{\text {sum }}$ scale of the diagram reflects the smoothed values. Interpolation smooths out energy surges induced by strong earthquakes, so it allows isolating energy clusters of weak events combined into the chains. The diagrams can be built for any range of magnitudes: $2.2 \leq \mathrm{M} \leq 5$.6. The slope of cluster chains reflects the velocity and direction of seismic activity propagation. The ratio of the spatial projection (in $\mathrm{km}$ ) to the time projection (in years) determines the velocity of this process. The most representative sequences with a high spatiotemporal correlation coefficient were considered for different time periods (for two periods of each projection zone). The representativeness of the chains is estimated as the test statistics of the correlation coefficient significance $(t)$, which depends on $r$ value and the number 
of earthquakes in the sequence. If value of indicator $t$ exceeds the tabulated value of the Student's coefficient, the chain is determined to be as not random.

\section{Information Software Environment}

The software and information basis of the research is implemented in the Windows operating system. Using GMT software (Wessel and Luis, 2017), requests are made to the databases of the initial vector and raster information for subsequent processing in other programs. The topographic data source is GTOPO 30 (USGS EROS, 2019). Seismic data is loaded into the PostgreSQL DBMS supported by the Spatial Data Management Modules of the 1C-system being a software development by the $1 \mathrm{C}$ Company. This program allows one to create compound queries to databases and implement the algorithms of a complex mathematical basis. Used module includes a vector GIS that supports the ESRI Shapefile format, but the functionality for working with cartographic information is limited: there are no tools for vector information editing and raster information displaying. Therefore the following free and open source systems are used to integrate various types of cartographic information: QGIS (2019) by the QGIS Development Team with extension by the GRASS Development Team (Fig. 3).

The data exchange between GIS 1C and QGIS is organized by using external interfaces. The interaction between PostGIS and external DBMS - PostgreSQL with PostGIS extension is done using OLE Automation and the ADO DB interface. Resulting data are uploaded from the 1C system to the PostGIS server for subsequent submission to QGIS. A layer of total amount of energy of earthquakes released inside projection areas for formation of $\mathrm{LgE}_{\text {sum }}$ diagrams is obtained by this way (Fig. 3). Calculation of the fault network anisotropy is performed in the $1 \mathrm{C}$ system. The resulting table of anisotropy estimations is unloaded into Microsoft Excel (Fig. 3). The procedure of seismic data projecting for constructing spatiotemporal charts is also organized in the $1 \mathrm{C}$ system with the subsequent data transfer to the MathGL graphing program (Fig. 3). The used information and software allows one to display the complex results of statistical analysis of the epicentral field, comparing them with the structural and topographic features of the study area.

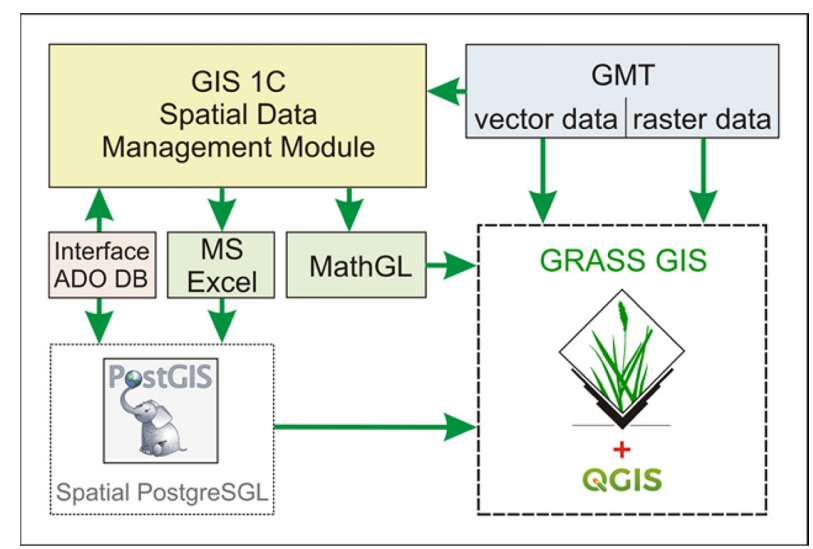

Figure 3. The conceptual scheme of information and software data exchange.

\section{Results}

\section{Analysis of Fracture Network Anisotropy}

The projection zone I covers an epicentral field part of the Barguzin depression and interdepression link between the Barguzin and Amut depressions (Fig. 4, a, b). The analysis of the anisotropy of this region shows that the maximum calculation of the number of faults has a northeast azimuth $30-60^{\circ}$ (sidebar of Fig. 4, a). This orientation is parallel to the Barguzin branch (Table 1), bordering the Barguzin depression (Petit and Déverchère, 2006). Other values are insignificant and several times less than the maximum value. In accordance with these results, the spatial axis azimuth of the projection area I is $\mathrm{Az}=45 \pm 5^{\circ}$.

The projection zone II includes the epicenters concentration of the northeast part of Kitchera depression and the southwest Upper Angara depression (Fig. 4, b). For the considered area, the fracture directions define two intersecting orientations. The rose chart II shows the maximum azimuth value of the strike range of faults $45-75^{\circ}$. The second-largest value of the number of faults corresponds to the azimuth of $105-135^{\circ}$ (sidebar of Fig. 4, a). For other azimuths, the quantity of faults is insignificant or equal to zero. Therefore, the orientation of spatial axis of the projection area II is $\mathrm{Az}=60^{\circ}$, within the range of the maximum quantity of faults of the rose chart.

The projection zone III covers the main parts of the Upper Angara and the Muyakan depressions (Fig. 4, a). A greater number of faults in this area relates to the srike range $60-90^{\circ}$ (sidebar of Fig. 4, a) corresponding to the Upper Angara branch stretching (Table 1). This is due to a change of the orientation of the main dislocations during the transition from northeast direction of Upper Angara branch zone to a sub latitudinal direction of the Muyakan branch zone. Also, some quantity of faults is in the adjacent azimuth range of $90-120^{\circ}$, and an insignificant quantity is allocated in the other azimuth's range. Thus, the projection area III is rotated $80^{\circ}$.

The fracture density, reflecting the heterogeneous fracture distribution, are represented in (Kuz'mina and Novopashina, 2018; Novopashina and Kuz'mina, 2019). All three projection areas include zones of abundant dislocations, where the shape of contour lines of fracture density reflects the anisotropy of the BRS fault network.

\section{Identifying of Slow Migrations of Seismic Activity}

In the northeast BRS area, where zones of seismic data collection were set, there are multiple swarms of earthquakes, systematically occurring in the same areas. Swarms are spatiotemporal groups of seismic events of moderate intensity whose main-shock energy is not greater than the energy of other shocks (Solonenko and Solonenko, 1987). They are associated with some concentrations of epicenters (Fig. 4, b), include strong seismic events of magnitudes M 5-6 and characterized by energy $\mathrm{E}>10^{11} \mathrm{~J}$, and relate to the areas with density lower than that for migrations of seismic activity, initiated by swarms, recorded in areas of intensive fracturing. Migrations are sequences of seismic energy clusters, which include events of weak and moderate intensity. The most representative spatiotemporal sequences of correlation coefficient of $0.74 \geq|r| \geq 0.85$ are marked with ellipses in Fig. 5. 

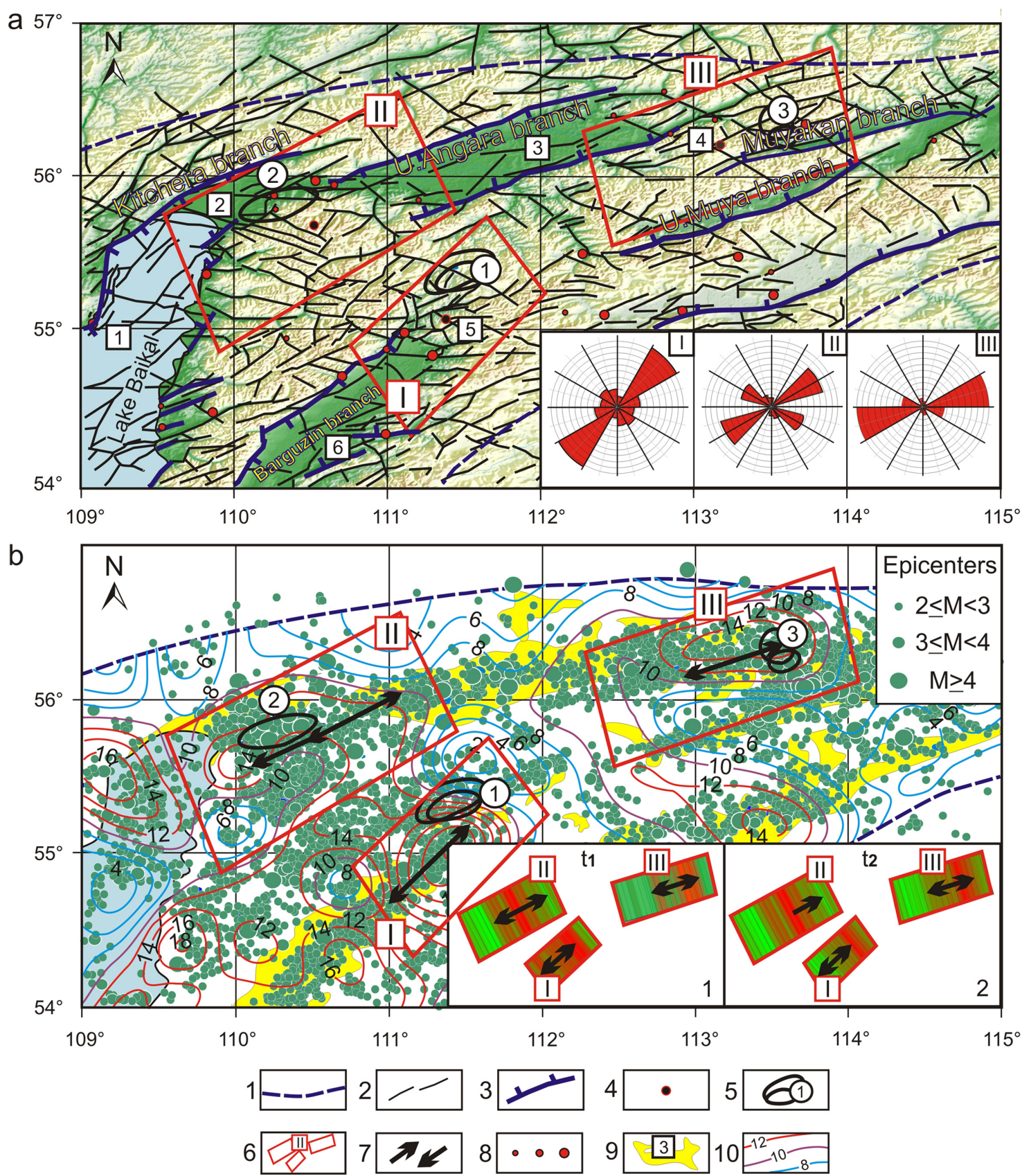

Figure 4. The location of the projection zones I, II, III in the northeast part of the Baikal rift: a - relief and active faults (Lunina, 2016), bmap of the epicentral field. 1 - contour of the BRS, 2 - active faults of the BRS, general branches of BRS NE-part, 4 -projection center points, 5 - swarms of earthquakes (Solonenko and Solonenko, 1987; Melnikova et al., 2007) with their numbers in circles (1 - Amut 19791981, 2 - Kitchera (Kichera) 1999, 3 - Angarakan 1979-1983), 6-zones of seismic data projection with their numbers (Roman numerals in squares), 7 -directions of seismic activity migration front, 8 -thermal springs of different temperature (Lysak, 2002), 9-the BRS depressions with their numbers in the squares (1 - Baikal, 2 - Kicthera, 3 - Upper Angara, 4 -Muyakan, 5 -Amut, 6 - Barguzin), 10 - contour lines of crust's fracture density for a pallet $0.37^{\circ} x 0.37^{\circ}$ from (Novopashina and Kuz'mina, 2019). The sidebar Figure 3, a, presents azimuths rose charts of 5-degree projection areas I, II, III, respectively. The sidebar 1 Figure 3, b-the total amount of seismic energy (Lg $E_{\text {sum }}$ over the first time period (t1), sidebar 2 Figure 3, b-the total amount of seismic energy (LgE $\left.E_{\text {sum }}\right)$ over the second time period (t2).

The significance of $\mathrm{r}$ exceeds the tabulated values of the Student's coefficient at a confidence level $\mathrm{p}=0.9995$.

The diagrams obtained for the projection areas indicated in Fig. 4 show the development of a seismic process over the different periods of seismic activation, when the level of seismic activity allows inspection of migration (Fig. 5).
The spatiotemporal diagram of parameter $\lg \mathrm{E}_{\text {sum }}$ of the seismic data projection zone I (shown in Fig. 4) is presented in Fig. 5, a. The graph includes two periods of seismic activity. The first period (1976-1988) $-t_{1}$ on the sidebar 1 of Fig. 4 , b, includes migrations of $\lg E_{\text {sum }}$, propagating from the Amut swarm 1979-1981 (see Fig. 4, a, b). This swarm occurred at the border between the maximum and minimum values of 


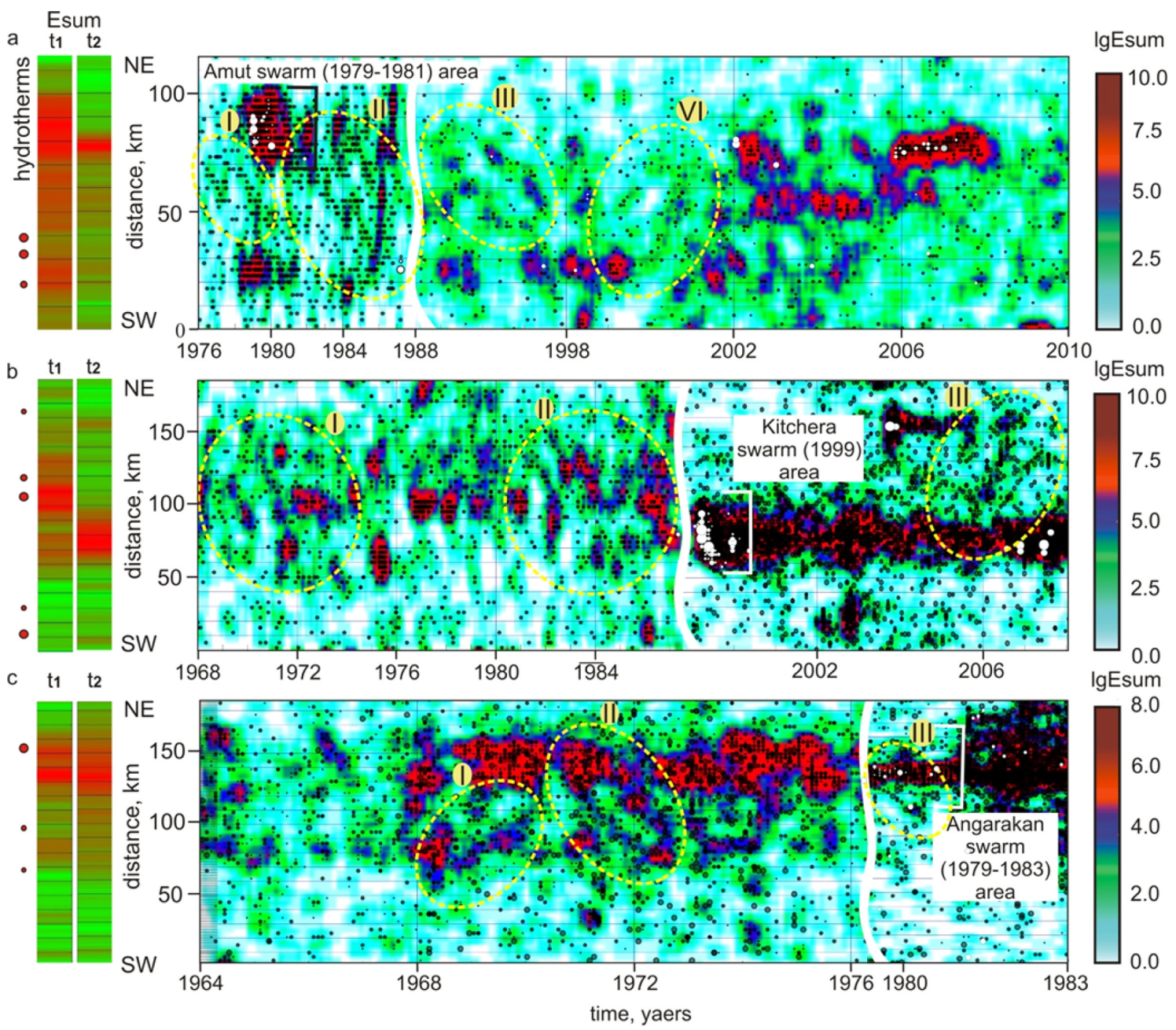

Figure 5. Spatiotemporal diagrams for projection zones of seismic data, shown in Figure 3 for zone I using (Novopashina and Kuz'mina, 2019) (a), for zone II (b), for zone III (c). "Distance" is the distance along the spatial axis (Ax) of the projection zones. The diagram is plotted by the MathGL program (MathGL, 2019). The graph consists of two layers: the layer of interpolated $L_{g} E_{\text {sum }}$ values (color) is covered by the layer of seismic event points. The scale of $L g E_{\text {sum }}$ is given for weak events $(M \leq 2.8)$. The figure combines the spatiotemporal diagrams for different time periods of seismic activity: $t_{1}$ and $t_{2}$.

the fracture density (Fig. 4, b, Fig. 5, a) and is characterized by strong seismic events $(\mathrm{M}=5)$. The trend of seismic energy directional propagation from a cluster of Amut swarm main seismic event has been isolated in a previous study (Novopashina and Kuz'mina, 2019). The 22year northeast-southwest propagation of seismic process over a distance of 110 kilometers along the Barguzin fault zone corresponds to a velocity of about $5 \mathrm{~km} / \mathrm{yr}$. Higher-velocity (10-40 km/yr) multidirectional chains of seismic energy maxima are superimposed on the main trend (yellow dotted ellipse I, II, in diagram 5, a). The second time interval (1995-2010) $-t_{2}$ on the sidebar 2 of Fig. 4, b includes some events during the time interval 2005-2007 which occurred near the Amut swarm area at the places where the shock chains change (ellipse II, III in diagram 5, a) their direction. These migrations, characterized by rate of about $20-35 \mathrm{~km} / \mathrm{yr}$, are spaced along the same areas as the migrations of the previously considered period 1974-1988. This area of $\mathrm{LgE}_{\text {sum }}$ sequences corresponds to the area of maximally fractured crust, bordered by regional faults, where many hydrothermal springs are located.

The graph for the seismic data projection area II (in Fig. 4) is presented in Fig. 5, b. Zone II covers the 1999 Kitchera earthquake swarm area that included events of maximum magnitudes $\mathrm{M}=5.6$ and $\mathrm{M}=6.0$ (Melnikova et al., 2007). The first period of seismic activity (19681986) $-t_{1}$ on the sidebar 1 of Fig. 4 , b, presented by the diagram of Fig. 5 , b, is characterized by earthquake sequences (dotted ellipse I, II in Fig. 5, b), extending to the northeast from the Kitchera swarm which occurred in 1999 at the places, where the shock chains change (ellipse II in diagram 5, b) their direction. Migration rate vary in the range of $30-45 \mathrm{~km} / \mathrm{yr}$. The second time period (1999-2008) $-\mathrm{t}_{2}$ on the sidebar 2 of Fig. 4, b, presented by the diagram Fig. 5, b, is characterized by seismic activity propagation episodes (ellipse III in Fig. 5, b). Visible sequences recur in the same area as migrations of the first considered period. The slope of the ordered sequences does not change significantly from period to period, which indicates an approximately constant propagation rate $(30-40 \mathrm{~km} / \mathrm{yr})$ in this zone over decades.

The diagrams for projection area III of Fig. 4 are in Fig. 5, c, and show the development of seismicity of the 1979-1983 Angarakan swarm of maximum earthquake magnitude about $\mathrm{M}=4.4$ (Solonenko and Solonenko, 1978). The results of seismic energy $\left(\mathrm{LgE}_{\text {sum }}\right)$ data collection over the two different periods $\left(t_{1}\right.$ and $\left.t_{2}\right)$ are presented in the side- 
bar 1 and 2 of Fig. 4, b, respectively. The $\mathrm{LgE}_{\text {sum }}$ chains, clearly visible between 1964 and 1976 (period $t_{1}$ ), are highlighted with ellipses I, II in Fig. 5, c. Migrations of opposite directions, characterized by the rate of about $40-46 \mathrm{~km} / \mathrm{yr}$, pass through a fractured zone located to the southwest of the zone of Angarakan swarm, which occurred later on (during the period $\mathrm{t}_{2}$ ). Ellipse 3 shows that the migration sequence changes its direction at the future Angarakan earthquake swarm generation site. The projection of thermal springs onto the spatial axis of the diagram is connected with the regional faults bordering the fractured zones. In the second period, the Angarakan swarm initiates chains of earthquakes, also spreading through this fractured area at a rate of about 45 $\mathrm{km} / \mathrm{yr}$.

The approximate longitudinal size of the migration zones is $70 \mathrm{~km}$, which corresponds to the length of the space between blocks bounded by deep normal and strike-slip faults associated with the manifestation of hydrothermal springs and characterized by the high value of thermal flow and geothermal gradient of the subsoil of the studied area. The maximum heat flux values in the northeastern part of BRS are related with the northeastern part of the Barguzin depression and the sides of the Kitchera and Upper Angara valleys, where heat flow reaches more than $100 \mathrm{~mW} / \mathrm{m}^{2}$ (Lysak, 2002).

\section{Deep Structure of the Lithosphere in Seismic Activity Migra- tion Zones}

Depth sections along profiles 1-4 (the inserts, Fig. 6, a), constructed after (Mats et al., 2001; Zorin and Turutanov, 2003; Petit and Déverchère, 2006; Pospeev, 2012; Turutanov, 2018), are shown in Fig. 6, b. The selected profiles intersect the zones of earthquake migration sequences: profile 1 strikes sub-perpendicular to projection zone I, profile 2 and profile 3 intersect projection zone II and zone III respectively. Deep structure of the lithosphere beneath the investigated area (Fig. 2) is characterized by the following features. The mean crust thickness of the northeast BRS is $41-42 \mathrm{~km}$, thickened beneath horsts and thinned beneath grabens (Mats et al., 2001). The crustal thickness is minimal (up to 35 $\mathrm{km}$ ) beneath the Barguzin, Kitchera, Upper Angara, Muyakan and Muya basins (Sherman et al., 1992). The modeling results for rheological properties of the Earth's crust showed thinning of effective elastic thickness of the lithosphere is about $25-30 \mathrm{~km}$ in the northeastern BRS (Petit et al., 2008). The investigated area exhibits gravity anomaly associated with the upper-section low-density Paleozoic granite batholith exposed (Insert 1, Fig. 6). A 5-30 km thick batholith intrudes the host rocks composed primarily of the Riphean gneisses, schists and Proterozoic terrigenous-carbonate rocks. The batholith shape is conformable to the strike of tectonic structures. Anomalously low values of gravity correspond to a large thickness of granite batholith (cross sections, Fig. 6, b) (Turutanov, 2018). At a depth of about $30 \mathrm{~km}$ from the batholith basement, there is the crustal conductive layer, most likely fluid-saturated (Pospeev, 2012) (Fig. 6, b). Beneath the basins this layer is at a depth ranging from $10-7$ to $30-33 \mathrm{~km}$, beneath the uplifts from $15-17$ to $33-35 \mathrm{~km}$. Water in this layer can be released as a result of active reduction of trivalent iron oxides by hydrogen coming from the lower layers and moving along the schist crystals whose permeability increases with time (Letnikov, 2006). A granite shield is not permeable to fluids, as a result of which the water can accumulates beneath the granite layer and reaches the surface only in certain places due to pressure gradient.

Beneath the investigated area the existence of mantle plume is supposed at the beginning of the Late Cenozoic (Fig. 6, a). The plume stem, with a roof located at a depth of about $150 \mathrm{~km}$, which probably has not cooled down yet, still retaining its anomalous properties, is a potential cause of the asthenospheric protrusion in the northeastern BRS (Zorin and Turutanov, 2003). The modern geophysical techniques identify thinning of the lithosphere to $70 \mathrm{~km}$ beneath the investigated area as compared with a $100-140 \mathrm{~km}$ thick lithosphere of the ancient and geodynamically stable Precambrian Siberian craton (Petit and Déverchère, 2006). This part of the BRS is characterized by elevated values of the heat flux, (reaching $170 \mathrm{~mW} / \mathrm{m}^{2}$ ), geothermal gradient and numerous hydrothermal outlets. The hottest thermal springs are observed on mountain slopes, where the deep-seated faults are exposed. Geothermal anomalies and hydrothermal activity can be associated with the rise of asthenospheric domes and the presence of magmatic chambers under the rift depressions, which are the source of deep intensive heat entering the Earth's surface along deep faults as transit zones (Lysak, 2002).

\section{The Depth of Seismic Activity Migration}

The analysis of reliable hypocentral depths over the instrumental period 1974-2014 (BRSC GS RAS, 2019) for the northeastern BRS shows that the maximum earthquake focal depths $35-40 \mathrm{~km}$ are related to the northern normal faults of the of Ezovsko-Bolsherechensk system and South Angara fault. Hypocentral depths $25-35 \mathrm{~km}$ are typical of the faults bordering the northeastern Barguzin basin, for the northeastern Muyakan fault, central South Angara fault, and central Upper Muya fault. Hydrothermal springs are concentrated on the surface areas beneath which the earthquake focal depths are maximum. In the rest of the areas, the hypocentral depths do not exceed $10-15 \mathrm{~km}$. The depth sections along profiles 1-4 in Fig. 6, b show interpolated hypocentral depths with an error not more than $5 \mathrm{~km}$ (yellow dotted contour line). Migrating earthquakes occur in the mid-crust at depths ranging from 10 to 35 $\mathrm{km}$ in the excessive fractured zones (Fig. 4, b) beneath the granite batholite basement. The hypocentral depth values vary within the fluidsaturated layer (Fig. 6, b). A contour line of the hypocentral depths is concordant with that of the granite batholite basement. The maximum granitoid thickness $20-30 \mathrm{~km}$ in the seismic migration zones (profiles 1-4 in Fig. 6, b) corresponds to the minimum gravity values (Insert 1 in Fig. 6, a). For projection zone I, the earthquake focal depths vary from $15-25 \mathrm{~km}$ on profile 1 to $25-30 \mathrm{~km}$ on profile 2 . The hypocentral depths of zones II (profile 3) and III (profile 4) are within range 20-35 km. Earthquake swarms - an initial link in the migration chain - occur at the same depths as seismic activity migrations.

\section{Discussion}

Analysis of the epicentral field and the fracture network using digital cartography allows identifying the features and development patterns of faulting, and the relationship between faulting and seismicity, occurring at the northeast flank of the Baikal rift. Analysis of the anisotropy of the fault network allows us to estimate more accurately the trend of propagation of seismicity. The prevailing azimuth of the active faults and 

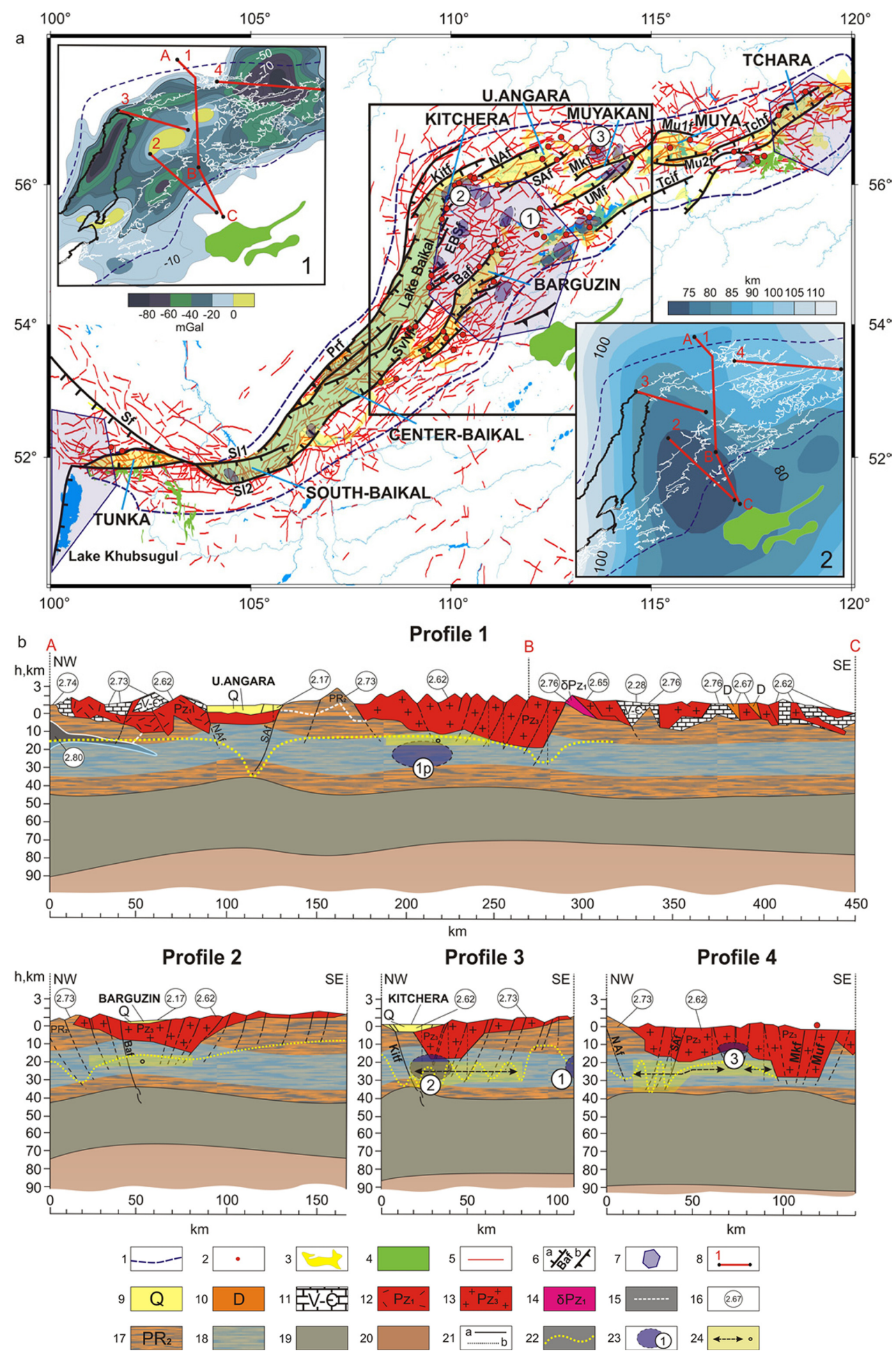

Figure 6. Structural-tectonic scheme of the BRS: a - a map of active faults in the BRS (Lunina, 2016), larges along profiles 1-4 (after Turutanov, 2018), with additions. 1 - the contour of the BRS, 2 - thermal springs. 3 - basins in the BRS, 4 - volcanic fields, 5 - active faults, 6 branches: a-normal faults and oblique slips named after (Mats et al. 2001; Krivonogov and Safonova, 2017) (see the names in Figure 1 Legend), b-reverse faults (Mats et al., 2001), 7 - Late Cenozoic mantle plumes (Zorin and Turutanov, 2003), 8 - profiles of depth sections, 9 Quaternary basin fill deposits $Q, 10$ - deposits $D, 11$ - terrigenous-carbonate rocks $V$ - $G, 12$ - granitoids $P z_{1}, 13$ - granitoids $P z_{3}, 14$ - diorites $P z_{1}, 15$ - indicated density contrast, 16 - rock density $\left(\mathrm{g} / \mathrm{cm}^{3}\right) .17$ - gneisses, crystalline schists $P R_{2}$ (Turutanov, 2018$), 18$ - highly conductive fluid-saturated layer (Pospeev, 2012), 19 - upper mantle (with Moho based on the data from (Turutanov, 2018)), 20-asthenosphere (depth to the top of the asthenosphere roof after Petit and Déverchère, 2006), 21 -active faults (a-real, b-inferred) (Sherman et al., 1984; 1992), 22 - interpolated hypocenter depths (from the data of BRSC GS RAS, 2019), 23 - earthquake swarms (1p-projection of Amut swarm 19791981, 1 - Amut 1979-1981, 2 - Kitchera 1999, 3-Angarakan 1979-1983) (depth values selected after Radziminovich, 2010), 24 - seismic activity migration areas where the black arrows show the main directions of migration process. Insert 1 - a map of gravity field (mGal) reflecting the granite batholith thickness (Turutanov, 2018). Insert 2 - a map of the depth to the top of the asthenosphere roof (Petit and Déverchère, 2006). 
strike of branches (Table 1) inside projection zone corresponds to the axis of the fracture density maxima elongation (see Fig. 4, b).

The spatial distribution of earthquake foci in the migration chains depends on magnitude of the earth's crust fracture. In the previous study (Novopashina and Kuz'mina, 2019) zones of LgEsum extensionwere characterized as areas of intensive fracturing and diffuse heat flow, limited by deep faults with hydrothermal activity. Strong seismic events and swarms, observed at the edges of the migration sequences are, as a rule, connected with deep faults separating the fractured space between consolidated blocks of grater lithosphere elastic layer thickness (Mordvinova et al., 2016). Seismic events of weak and moderate intensity are the basis of $\mathrm{LgE}_{\text {sum }}$ chains, recorded along isometric fault density maxima, as shown by the major directions of the rose charts (see Fig. 4, a, b). Because most of the weaker seismic events happen in fractured space between the Earth's crust blocks, this is an area of tectonic stress unloading (Seminsky and Tugarina, 2011), and migration chains mark the process of sequential relaxation in the direction of deformation front propagation.

A spatiotemporal visualization of seismic activity allows establishing that the redistribution of stresses, and propagation of deformation caused by strong seismic events as shocks of different intensities, are not limited by the dislocations where an initial earthquake or a swarm occurred. The interaction of adjacent faults (fault interaction) is manifested by that way (Grapes and Holdgateb, 2014; Žalohar, 2018). An earthquake occurred on one of the faults causes a change in stress state of adjacent faults and in neighboring lithospheric blocks (Rogers and Dragert, 2003; Lin and Stein, 2004). This process occurs by elastic stress transfer in the upper crust (Tung et al., 2018) and by elastic-plastic stress transfer through the lower crust and upper mantle sequentially from one active segment to another (Chéry et al., 2001; Pollitz et al., 2003; Bykov, 2018). The complex of different migration rates is an integral seismic process, characterized by models of elastic and elastic-plastic stress transfer (Novopashina and Sankov, 2018).

Comparing the development of a seismic process over the different time periods, one can observe $\mathrm{LgE}_{\text {sum }}$ chains of similar velocities that are most likely determined by the properties of the environment, where ordered sequences take place, and by the structural features of the lithosphere in the migration zones (Fig. 6). The technique used herein allows identifying slow migrations measured in kilometers per year, which are best explained by the model of slow elastoplastic stress transfer through the lower crust-upper mantle layers. In the northeastern BRS, in the areas with occurrence of intensive migration process, the Earth's crust is thinned and the plastic layer is thickened so that the interaction distance between the brittle and plastic lithospheric layers is minimal. The analysis of earthquake focal depth distributions shows that seismic activity migrations occur in the areas of a larger granite-layer thickness. The granite shield like a kind of a screen for fluids prevents convective heat and mass transfer as a result of which heat coming from the asthenospheric protrusion under the northeastern BRS is stored beneath the batholith (Insert 2 in Fig. 6). Therefore, viscosity of a brittle seismoactive layer of the Earth's crust in $\mathrm{LgE}_{\text {sum }}$ propagation areas may be reduced due to the warming up of the fluid-saturated layer which is located within the brittle deformation layer beneath the thickened granite cover. Today, there is the conception of aqueous fluid's participation in seismic activity migration accompanying the process of horizontal and vertical interaction, both between different lithosphere layers and the upper mantle and lower-crustal layers (Marone et al. 1991; Chéry et al. 2001; Jónsson et al., 2002; Bürgmann and Dresen, 2008; Becken et al., 2011; Kariche et al., 2018; Tung and Masterlark, 2018; Tung et al., 2018). Fluid can both cause displacement through fault stepover and reduce displacement intensity, as a result of which tectonic stress relaxation is associated with occurrence of numerous small and moderate events. Thus, it had been concluded that the migration zones are likely characterized by conditions most appropriate for the tectonic stress relaxation: viscosity reduction of a fractured brittle layer of the Earth's crust due to the warming up of the fluid-saturated layer beneath a thick granite layer.

The areas where the ordered sequences change direction can be identified on the spatiotemporal diagrams (Fig. 5). The strong events and earthquake swarms occurred in these sites. In some cases, the sequences, starting from such an event, are related to the residual Coulomb stress relaxation from a strong event or swarm, of in other cases, migration can act as a trigger for strong events and swarms. Thus, the boundaries of the migration zones and stress relaxation can be considered as locations of a high probability of occurrence of high-intensity seismic events $(M \geq 5)$.

\section{Conclusions}

A systematic approach utilizing GIS technology applied to the seismic process analysis allows us to analyze a large amount of instrumental data using mathematical and statistical tools. The comprehensive research is an example of employing qualitative and quantitative seismogeologic information that gives substantial advantages for detailed analysis of the epicentral field and morphostructural features of the territory. The revealed patterns can be considered for extrapolation of the seismic process over time and zoning the territory depending on the way of seismic energy realization.

The obtained research results allow us to do the following conclusions:

1) The strike of active faults is concordant with main branches of the Baikal rift and with the orientation of lithosphere fracture density maxima elongation.

2) An analysis of the anisotropy of the fracture network allows us to define the directions of migrations, propagating at a rate of 30 to 45 $\mathrm{km} / \mathrm{yr}$.

3) Hypocentral depths in seismic activity migration zones correspond to the depth of occurrence of the fluid-saturated layer beneath the thickened granite batholith basement. Large granitoid thickness is a probable cause of heat accumulation in the middle/lower crust and the warming up of the fluid accompanying process of stress transfer. The accumulated heat and moving fluid reduce the viscosity of seismoactive layer and intensity of earthquakes.

4) The stress changes induced by a large seismic event or high-energy earthquake swarm may transfer through the lower plastic layers of the lithosphere and thus affect the brittle fluid-saturated layer of the adjacent areas giving rise to subsequent stress relaxation occurring as diverse migration chains primarily directed along the fault zone.

5) Seismic activity propagation in the fractured crust can be a reflection of the relaxation of residual stress of large magnitude events $(M \geq 5)$, as well as to be a trigger for such events and earthquake swarms occurring 
in places, where migration change their direction.

This research can serve the purposes of further GIS modeling, mapping of geodynamic zones and forecasting of seismic process development.

\section{Acknowledgements}

The authors are thankful to researchers of the Institute of the Earth's Crust of the Siberian Branch of the Russian Academy of Sciences for scientific advice and discussions, as well as to the colleagues from the Geophysical Survey of the Russian Academy of Sciences for providing catalogs of earthquakes of the study area. Also the authors are grateful to reviewers Rodolfo Carosi, John Geissman and editors of the Episodes journal for reviewing, remarks, ideas, valuable advices and correction on improving the article. Authors are also very thankful to reviewer John Geissman, translator Tatyana Leshkevich and Robert Hanshaw for help with the English translation and English proofreading. This work is supported by the integration basic research program № 0341-2016-0001, block V.

\section{References}

Bornyakov, S.A., Seminsky, K.Zh., Buddo, V.Yu., Miroshnichenko, A.I., Cheremnykh, A.V., Cheremnykh, A.S., and Tarasova, A.A., 2014, Main regularities of faulting in lithosphere and their application (based on physical modelling results). Geodynamics \& Tectonophysics, v. 5, pp. 823-861. doi:org/10.5800/GT-2014-5-4-0159

BRSC GS RAS, 2019, Baykal Regional Seismological Center, Geophysical Survey of the Russian Academy of Sciences, Irkutsk, dataset of earthquakes for the period 1964-2002. http://seis-bykl.ru/ [accessed 27 February 2020].

Bykov, V.G., 2018, Prediction and observation of strain waves in the Earth. Geodynamics \& Tectonophysics, v. 9, pp. 721-754. doi:org/10.5800/GT2018-9-3-0369

1C: GIS Spatial Data Management, 2019, Module for 1C: ERP and 1C: KA2. https://solutions.1c.ru/catalog/gis. [accessed 26 June 2019].

Calais, E., Vergnolle, M., San'kov, V.A., Lukhnev, A.V., Miroshnitchenko, A.I., Amarjargal, S., and Déverchère, J., 2003, GPS measurements of crustal deformation in the Baikal-Mongolia area (1994-2002): Implications for current kinematics of Asia, Journal of Geophysical Research: Solid Earth, v. 108(B10), 2501. doi:org/10.1029/2002JB002373

Cheloni D., Giuliani R., D'Agostino N., Mattone M., Bonano M., Fornaro G., Lanari R., Reale D., and Atzori S., 2016, New insights into fault activation and stress transfer between en echelon thrusts: The 2012 Emilia, Northern Italy, earthquake sequence. Journal of Geophysical Research: Solid Earth, v. 121, pp. 4742-4766.

Chéry, J., Merkel, S., and Bouissou, S., 2001, A physical basis for time clustering of large earthquakes. Bulletin of the Seismological Society of America, v. 91, pp. 1685-1693.

Déverchère, J., Houdry, F., Diament, M., Solonenko, N.V., and Solonenko, A.V., 1991, Evidence for a seismogenic upper mantle and lower crust in the Baikal rift. Geophysical research letters, v. 18, pp.1099-1102.

Déverchère, J, Petit, C., Gileva, N., Radziminovitch N., Melnikova V., and San'kov, V., 2001, Depth distribution of earthquakes in the Baikal rift system and its implications for the rheology of the lithosphere. Geophysical Journal International, v. 146, pp. 714-730. doi:org/10.1046/ j.0956-540x.2001.1484.484.x

Ding M., and Lin J., 2014, Post-seismic viscoelastic deformation and stress transfer after the 1960 M9.5 Valdivia, Chile earthquake: effects on the 2010 M8.8 Maule, Chile earthquake. Geophysical Journal Inter- national, v. 197, pp. 697-704.

Dolgaya A.A., Gerus A.I., and Vikulin A.V., 2016, Interpretation of migration of the geodynamic activity of the geomedium by the propagation of rotational waves in it. Processes in GeoMedia, v. 8, pp. 15-21.

Epov, M.I., Nevedrova, N.N., and Sanchaa, A.M., 2007, A geoelectrical model of the Barguzin basin in the Baikal rift zone., v. 7, pp. 626-641. doi:org/10.1016/j.rgg.2007.06.001

Gorbunova E.A., and Sherman S.I., 2012, Slow deformation waves in the lithosphere: registration, parameters, and geodynamic analysis (Central Asia). Russian Journal of Pacific Geology, v. 6, pp. 13-20.

Grapes, R.H., and Holdgateb, G.R., 2014, Earthquake clustering and possible fault interactions across Cook Strait, New Zealand, during the 1848 and 1855 earthquakes. New Zealand Journal of Geology and Geophysics, v. 57, pp. 312-330.

GRASS Development Team, 2019, Geographic Resources Analysis Support System (GRASS) Software, Version 7.4.1. Open Source Geospatial Foundation. https://grass.osgeo.org [accessed 26 June 2019].

Krivonogov, S.K., and Safonova, I.Y., 2017, Basin structures and sediment accumulation in the Baikal Rift Zone: Implications for Cenozoic intracontinental processes in the Central Asian Orogenic Belt. Gondwana Research, v. 47, pp. 267-290.

Kuz'mina, E.A., and Novopashina, A.V., 2018, Groundwater outflows and fault density spatial relation in the Baikal rift system (Russia). Acque Sotterranee - Italian Journal of Groundwater, v. 24, pp. 51-60. doi:org/ 10.7343/as-2018-324.

Letnikov, F.A., 2006, Fluids in endogenic processes and problems of metallogeny. Russian Geology and Geophysics, v. 47, pp. 1271-1281.

Levina, E.A., and Ruzhich, V.V., 2015, The seismicity migration study based on space-time diagrams. Geodynamics \& Tectonophysics, v. 6, pp. 225-244. doi:org/10.5800/GT-2015-6-2-0178

Lin, J., and Stein, R.S., 2004, Stress triggering in thrust and subduction earthquakes and stress interaction between the southern San Andreas and nearby thrust and strike-slip faults. Journal of Geophysical Research, v. 109(B2), B02303. doi:org/10.1029/2003JB002607

Logatchev, N.A., 1984, The Baikal Rift System. Episodes, v. 7, pp. 38-42. doi:org/10.18814/epiiugs/1984/v7i1/009

Logachev, N.A., 2003, History and geodynamics of the Baikal rift, Russian Geology and Geophysics, v. 5, pp. 373-387.

Lukhneva, O.F., Zuev, F.L., and Balhanov, V.K., 2010, Mapping of topography heterogeneities based on fractal dimension (on example of the Baikal region). Russian Journal of Pacific Geology, v. 29, pp. 97-102.

Lukhnev A.V., San'kov V.A., Miroshnichenko A.I., Ashurkov S.V., Byzov L.M., San'kov A.V., Bashkuev Yu.B., Dembelov M.G., and Calais E., 2013, GPS-measurements of recent crustal deformation in the junction zone of the rift segments in the central Baikal rift system. Russian Geology and Geophysics, v. 54, pp. 1417-1426. doi:org/10.1016/j.rgg.2013.10.010

Lukhnev, A.V., San'kov, V.A., Miroshnichenko, A.I., Ashurkov, S.V., and Calais, E., 2010, GPS rotation and strain rates in the Baikal-Mongolia region. Russian Geology and Geophysics, v. 51, pp. 785-793.

Lunina, O.V., 2016, The digital map of the Pliocene-quaternary crustal faults in the southern east Siberia and the adjacent northern Mongolia. Geodynamics \& Tectonophysics, v. 7, pp. 407-434. doi:org/10.5800/ GT-2016-7-3-0215

Lunina, O.V., and Gladkov, A.S., 2007, Late Cenozoic fault pattern and stress fields in the Barguzin rift (Baikal region). Russian Geology and Geophysics, v. 7, pp. 598-609.

Lysak, S.V., 2002, Heat flow in the zones of active faults in the south of Eastern Siberia. Russian Geology and Geophysics, v. 8, pp. 791-803.

MathGL, 2019, A library for scientific data visualization. https://sourceforge.net/projects/mathgl/reviews [accessed 26 June 2019].

Mats, V.D., Ufimtsev, G.F., Mandel'baum, M.M., Alakshin, A.M., Pospeev, A.V., Shimaraev, M.N., and Khlystov, O.M., 2001. The Baikal Basin in the Cenozoic: Structure and Geologic History. Novosibirsk, Russia, 252 p.

Mats, V.D., 2012, The sedimentary fill of the Baikal basin: implications for rifting age and geodynamics. Russian Geology and Geophysics, v. 9. 
pp. 936-954.

Melnikov, A. I., Mazukabzov, A. M., Sklyarov, E. V., Vasiliev, E. P., 1994, Baikal rift basement: Structure and tectonic evolution. Bull. Cent. Rech. Explor. Prod. Elf-Aquitaine, v. 18, pp. 99-122.

Melnikova, V.I., Radziminovich, N.A., Chipizubov, A.V., Dobrynina, A.A., and Gileva, N.A., 2007, Activation of rifting processes in the Northern Cis-Baikal region: A case study of the Kitchera earthquake sequence of 1999. Izvestiya. Physics of the Solid Earth, v. 43, pp. 905-921.

Mordvinova, V.V., Kobelev, M.M., Treussov, A.V., Khritova, M.A., Trynkova, D.S., Kobeleva, E.A., and Lukhneva, O.F., 2016, Deep structure of the Siberian platform - Central Asian mobile belt transition zone from teleseismic data. Geodynamics \& Tectonophysics, v. 9, pp. 139-163. doi:org/10.5800/GT-2016-7-1-0198

Novopashnina, A.V., and San'kov, V.A., 2015, Migration of seismic activity in strike-slip zones: A case study of the boundary between the North American and Pacific plates. Russian Journal of Pacific Geology, v. 9, pp. 141-153.

Novopashina, A.V., and Sankov, V.A., 2018, Migrations of released seismic energy in various geodynamic conditions. Geodynamics \& Tectonophysics, v. 9, pp. 139-163. doi:org/10.5800/GT-2018-9-1-0342

Novopashina A.V., and Kuz'mina, 2019, Influence of crustal fracturing on the thermal springs and earthquake swarms distribution in the northeast part of the Baikal rift system (Russia) Acque Sotterranee - Italian Journal of Groundwater, v. AS29, pp. 23-36. doi:org/10.7343/as-2019-360

QGIS - The Leading Open Source Desktop GIS, 2019. https://www.qgis.org/ $\mathrm{ru} / \mathrm{site}$. [accessed 26 June 2019].

Obara K., and Hirose H., 2006, Non-volcanic deep low-frequency tremors accompanying slow slips in the southwest Japan subduction zone. Tectonophysics, v. 417, pp. 33-51. doi:org/10.1016/j.tecto.2005.04.013.

Petit, C., Burov, E., and Tiberi, Ch., 2008, Strength of the lithosphere and strain localisation in the Baikal rift. Earth and Planetary Science Letters, v. 269, pp. 522-528. doi:org/10.1016/j.eps1.2008.03.012

Petit, C., and Déverchère, J., 2006, Structure and evolution of the Baikal rift: a synthesis. Geochemistry Geosystems, v. 7, pp. 1-26.

Petit, C., Déverchère J., Houdry F., Sankov V.A., Melnikova V.I., and Delvaux D., 1996, Present-day stress field changes along the Baikal rift and tectonic implications. Tectonics, v. 15, pp. 171-119.

Petit, C., Koulakov, I., and Déverchère, J., 1998, Velocity structure around the Baikal rift zone from teleseismic and local earthquake traveltimes and geodynamic implications. Tectonophysics, v. 296, pp. 125-144. doi:org/10.1016/S0040-1951(98)00140-1

Pollitz, F., Vergnolle, M., and Calais, E., 2003, Fault interaction and stress triggering of twentieth century earthquakes in Mongolia. Journal of Geophysical Research: Solid Earth, v. 108(B10), pp. 2503.

Pospeev, A.V., 2012, The velocity structure of the upper mantle and regional deep thermodynamics of the Baikal rift zone. Geodynamics \& Tectonophysics, v. 3, pp. 377-383. doi:org/10.5800/GT-2012-3-4-0080

Radziminovich, N.A., 2010, Focal depths of earthquakes in the Baikal region: A review. Izvestiya Physics of the Solid Earth, v. 46, pp. 216-229. doi:org/10.1134/S1069351310030043

Radziminovich, N.A., Gileva, N.A., Melnikova, V.I., and Ochkovskaya, M.G., 2013, Seismicity of the Baikal rift system from regional network observations. Journal of Asian Earth Sciences, v. 62, pp. 146-161. doi:org/ 10.1016/ j.jseaes.2012.10.029

Rogers, G., and Dragert, H., 2003, Episodic tremor and slip on the Cascadia subduction zone: the chatter of silent slip. Science, v. 300(5627), pp. 1942-1943.

Rydelek P.A., and Sacks I.S., 2001, Migration of large earthquakes along the San Jacinto fault; stress diffusion from the 1857 Fort Tejon earthquake. Geophysical Research Letters, v. 28, pp. 3079-3082. doi:org/10.1029/ 2001GL013005

Sankov, V.A., Dneprovsky Yu.I., Kovalenko S.N., Bornyakov S.A., Gileva N.A., and Gorbunov N.G., 1991, The faults and seismicity of the North Muya geodynamic polygon, Novosibirsk, Russia, 111 p.

San'kov, V., Déverchère, J., Gaudemer, Y., Houdry, F., and Filippov A.,
2000. Geometry and rate of faulting in the North Baikal Rift, Siberia. Tectonics, v. 19, pp. 707-732.

Sankov, V.A., Lukhnev, A.V., Miroshnitchenko, A.I., Perevalova, N.P., Dobrynina, A.A., Sankov, A.V. and Lebedeva, M.A., 2017, Contemporary vertical crustal movements of Baikal region: long-term trends and time variations. Actual problems of science of Cis-Baikal, part 2, Irkutsk, Russia, 235 p.

Sankov, V.A., Lukhnev, A.V., Miroshnitchenko, A.I., Dobrynina, A.A., Ashurkov, S.V., Byzov, L.M., Dembelov, M.G., Calais, E., and Déverchère, J., 2014. Contemporary horizontal movements and seismicity of the South Baikal Basin (Baikal rift system). Izvestiya, Physics of the Solid Earth, v. 50, pp. 785-794. doi:org/10.1134/S106935131406007X

Sankov, V.A., Lukhnev, A.V., Miroshnitchenko, A.I., Perevalova, N.P., Dobrynina, A.A., Sankov, A.V. and Lebedeva, M.A., 2017, Contemporary vertical crustal movements of Baikal region: long-term trends and time variations. Actual problems of science of Cis-Baikal, part 2, Irkutsk, Russia, 235 p.

Seminsky, K.Z., and Tugarina, M.A., 2011, Results of comprehensive studies of the underground hydrosphere within the western shoulder of the Baikal rift (as exemplified by the Bayandai - Krestovsky cape site). Geodynamics \& Tectonophysics, v. 2, pp. 126-144. doi:org/10.5800/GT2011-2-2-0037

Shelly, D.R., 2010, Migrating tremors illuminate complex deformation beneath the seismogenic San Andreas fault. Nature, v. 436(7281), pp. 648-652. doi:org/10.1038/nature08755.

Sherman, S.I., and Gorbunova, E.A., 2008, Wave origin of fault activation in Central Asia on the basis of seismic monitoring. Fizicheskaya Mezomekhanika, v. 11, pp. 115-122.

Sherman, S.I., 2013, Deformation waves as a trigger mechanism of seismic activity in seismic zones of the continental lithosphere. Geodynamics \& Tectonophysics, v. 4, pp. 83-117. doi:org/10.5800/GT-2013-4-2-0093

Sherman, S.I., Levi, K.G., Ruzhich, V.V., Sankov, V.A., Dneprovskiy, V.I., and Rasskazov, S.V., 1984, Geology and seismicity of the BAM zone. Neotectonics, Novosibirsk, Russia, 356 p.

Sherman S.I., Seminsky K.Zh., Bornyakov S.A.., Adamovich A.N., Lobatskaya R.M., Lysak S.V., and Levi K.G., 1992, Faulting in the Lithosphere. Extensional zones. Nauka, Novosibirsk, 228 p.

Steacy S., Gerstenberger M., Williams C., Rhoades D., and Christophersen A., 2014, A new hybrid Coulomb/statistical model for forecasting aftershock rates. Geophysical Journal International, v. 196, pp. 918-923.

Solonenko, N.V., and Solonenko, A.V., 1987, Aftershock sequences and swarms of earthquakes in the Baikal rift zone. Nauka Press, Novosibirsk, Russia, 94 p.

Tapponnier, P., and Molnar, P., 1979, Active faulting and Cenozoic tectonics of the Tien Shan, Mongolia, and Baykal regions, Journal of Geophysical Research, v. 84, pp. 3425-3459. doi:org/10.1029/JB084iB07p03425

Tung, S., and Masterlark, T., 2018, Delayed poroelastic triggering of the 2016 October Visso earthquake by the August Amatrice earthquake, Italy. Geophysical Research Letters. doi:org/10.1002/2017GL076453

Tung, S., Masterlark, T., and Dovovan, T., 2018, Transient poroelastic stress coupling between the 2015 M7.8 Gorkha, Nepal earthquake and its M7.3 aftershock. Tectonophysics, v. 733, pp. 119-131.

Turutanov, E.Kh., 2018, The anomalies of gravity, deep structure and geodynamics of the Mongol-Siberian region, Irkutsk, Russia, $182 \mathrm{p}$.

Thybo, H., and Nielsen, C. A., 2009, Magma-compensated crustal thinning in continental rift zones. Nature, v. 457.pp. 873-876. doi:org/10.1038/nature 07688

USGS, EROS Archive - Digital Elevation Model - Global 30 Arc-Second Elevation (GTOPO30), 2019, https:/www.usgs.gov/ [accessed 26 June 2019].

Vikulin A.V., Makhmudov K.F., Ivanchin A.G., Gerus A.I., and Dolgaya A.A., 2016, On wave and rheidity properties of the Earth's crust. Physics of the Solid State, v. 58, pp. 561-571.

Wei, D.P., and Seno, T., 1998, Determination of the Amurian plate motion, in Mantle Dynamics and Plate Interactions in East Asia. Geodyn. Ser., 
v. 27 , pp. $337-346$

Wessel, P., and Luis, J.F., 2017, The GMT/MATLAB Toolbox, Geochemistry, Geophysics, Geosystems, v. 18, pp. 811-823. [accessed 26 June 2019].

Zonenshain, L.P., and Savostin, L.A., 1981, Geodynamics of Baikal rift zone and plate tectonics of Asia. Tectonophysics, v. 76, pp. 1-45. doi:org/10.1016/0040-1951(81)90251-1

Zalohar, J., 2018, Developments in Structural Geology and Tectonics

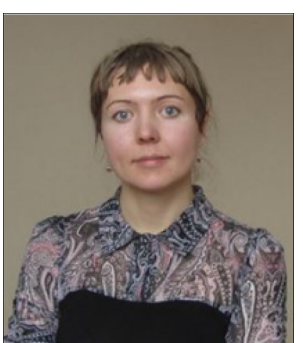

Anna V. Novopashina Candidate of Geology and Mineralogy, Researcher Institute of the Earth's Crust, Siberian Branch of RAS, Laboratory of recent geodynamics, 128 Lermontov street, Irkutsk 664033, Russia Tel.: +7(950) 1405788; e-mail; avn crust@mail.ru; ORCID ID https://orcid.org/ $0000-0003-1138-6706$
Chapter 34 - Strain Waves at the Tectonic Plates Boundaries. Developments in Structural Geology and Tectonics, v. 2, pp. 515-521. doi:org/ 10.1016/B978-0-12-814580-7.00034-4

Zorin, Yu.A., Turutanov, E.Kh., Mordvinova, V.V., Kozhevnikov, V.M., Yanovskaya, T.B., and Treussov, A.V., 2003, The Baikal rift zone: the effect of mantle plumes on older structure. Tectonophysics, v. 371, pp. 153-173. doi:org/10.1016/S0040-1951(03)00214-6

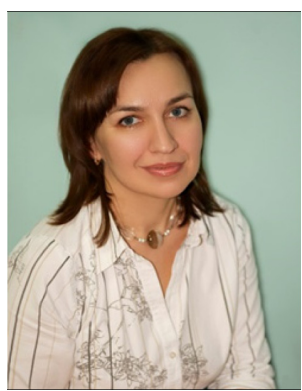

Olga F. Lukhneva Candidate of Geology and Mineralogy, Researcher Institute of the Earth's Crust, Siberian Branch of RAS, Laboratory of recent geodynamics, 128 Lermontov street, Irkutsk 664033, Russia Tel.: +7(914)8970330; ORCID ID https://orcid.org/0000-0001-99301871 